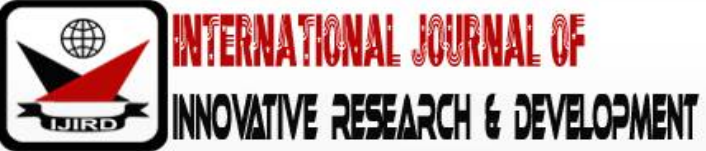

ISSN 2278 - 0211 (Online)

\section{Influence of Pupils Interpretation of Kenyan Sign Language on Academic Performance of Pupils with Hearing Impairment in Selected Public Primary Schools, Kenya}

\author{
Tom M Wawire \\ Masters Student, Masinde Muliro University, Kenya \\ Dr. Nick Namunga \\ Lecturer, Rongo University, Kenya
}

\begin{abstract}
:
The government of Kenya recognizes the importance of special needs education as a crucial sector for accelerating the attainment of Education for all students and the 2030 Millennium Development Goals. The purpose of this study was to establish the relationship between mastery of Kenya Sign Language (KSL) and academic performance of pupils with hearing impairment in public primary schools in western Kenya. Study objective was to find out the influence of pupils' interpretation of Kenya Sign Language on academic performance. The study employed a mixed research approach and a descriptive survey design to collect qualitative and quantitative data. Using purposive sampling technique, 12 head teachers, 93 teachers and 108 pupils with hearing impairment forming a sample size of 213 respondents. Research instruments used were a Likert scale questionnaire and interview schedule. Piloting of the questionnaire was done in a public special primary school for the pupils with hearing impairment in Birunda School for the Deaf in Trans Nzoia. The collected data was analysed using descriptive statistics of frequencies, percentages, means, standard deviation and Pearson correlation coefficient and inferential statistics of chi-square using the statistical package for social sciences [SPSS] program of version 23. Qualitative data was analysed by describing the emerging themes in relation to the study objectives. The study established that there was significant relationship between pupils' interpretation of KSL at $\mathrm{p}<0.05$. Therefore, the null hypothesis was rejected and concluded that mastery of KSL significantly influences academic performance. The results will help stakeholders in the education sector to establish how KSL is used in the teaching of pupils with hearing impairment in schools, hence providing valuable data on the current policy and practice in the field of education and training of teachers of the learners with hearing impairment. The following recommendations were made: pupils should be equipped with more interpretation and literacy skills for the KSL, further training in special needs education be given to teachers and adequate resources and support services be given to the learners.
\end{abstract}

Keywords: Interpretation, Kenyan sign language, academic performance, public primary schools

\section{Introduction}

Sign language is a form of communication that is gestural based. It has been known to be the first language of children with hearing impairment. Research has shown that when this language is used appropriately it facilitates learning which also allows mobility across other languages.

The use of signs to help pupils with hearing impairment learn dates back to the 19th century when Thomas Hopkins Gallaudet who pioneered education for the deaf in the United States, advocated for using sign language and finger spelling to help increase vocabulary and language development in pupils with hearing impairment (Daniels, 1996). In 1852, David Bartlett taught deaf children and their hearing siblings in a family school (Marschark\& Spencer, 2006). He discovered that signing and finger spelling not only helped the deaf children learn but it also helped their hearing siblings as well. Other educators in the hearing-impaired field made similar observations during the $19^{\text {th }}$ century and recommended that signing be used to help teach reading, spelling and writing to hearing impaired children (Hafer \& Wilson, 1989).

According to Imbiti (2014), the United Nations Universal Declaration of human rights of 1989 mandates removal of barriers such as communication mode that may hinder education progress of pupils with hearing impairment. The 1993 United Nations Standard rules on equalization of opportunities for persons with disabilities further suggests that pupils with hearing impairment access education in their national language (Ayiela, 2012). According to Adoyo (2007), education for the deaf in Kenya falls under the Ministry of Education, Special Education Division that deals with the administration of education of persons with special educational needs, and education for hearing impaired is one of them. Antia \& Stinson (1999) added that children with hearing impairment many years ago were once Africa's "FORGOTTEN" children as they were disowned by their own parents and the society at large. Others left them to the mercy of villagers or town Elders who 
often enslaved them. Unlike blindness, which craves for your sympathy, there is little or no sympathy for deafness. Deafness is not immediately visible or easily recognizable by passers-by. They further say that those decades ago, deaf children in Africa found love and compassion in the hearts of a few dedicated men and women (Chitiyo et al., (2015; Katitia, 2015).

According to Kimani \& Cecilia (2012), Deaf Education in Kenya is a constantly changing sector of the Kenyan education system that is focused on educating deaf, hard-of-hearing, and hearing-impaired Kenyan children. There are many organizations in Kenya, formed to protect the rights of Deaf Kenyans and promote progress in deaf education. The state of Kenyan deaf education is constantly changing and improving (Lewis, 2009). Bishop (1985) as cited in Makumi (1987) reveals that children in Zambia who begun their schooling in their first language fared well in their learning. In Kenya, Kenyan Sign Language (KSL) was adopted as a medium of instruction for learners with $\mathrm{HI}$ in 2004 after various modes were tried out and seemed not to fulfil the communication need of these learners. A study done by Lewis (2009) reveal that KSL is used in 32 out of 71 institutions for pupils with hearing impairment in Kenya. This shows a positive move towards the use of Kenyan Sign Language. However, Owiko (2009) reveals that there is need for further research on KSL. He recommended that investigations on measures to enhance the use of KSL in teaching to improve performance of learners with hearing impairment should be carried out. These views are echoed by Bunyasi (2010) who reveals that teachers' skills and experience in KSL are wanting and that there are inadequate resources in classes to support the learning of pupils with hearing impairment. The academic performance of children with hearing impairment was at stake. Therefore, this current study came in handy by looking at effect of mastery of KSL on academic performance in western region. From the year 2014 to 2018, the records from the County Education offices indicate poor academic performance in Kenya Certificate of Primary Education (KCPE) of the hearing impaired learners as shown in table 1 below. Western Region).

\begin{tabular}{|c|c|}
\hline Year & Mean Score \\
\hline 2014 & 248.3 \\
\hline 2015 & 247.2 \\
\hline 2016 & 242.5 \\
\hline 2017 & 249 \\
\hline 2018 & 246.8 \\
\hline Overall Mean & 246.76 \\
\hline
\end{tabular}

Table 1: Western Region Kcpe Results from 2014-2018

Source: County Education Offices in Western Region: 2018

Raising academic standards for all students and measuring student achievement to hold schools accountable for educational progress are central strategies for promoting educational excellence and equity in our schools. In United States of America for example, the No Child Left Behind Act (NCLB) of 2001 was designed to support state efforts, establish challenging standards, develop aligned assessments, and build accountability systems for districts and schools that are based on educational results (Mounty, 2001). Sign Language proficiency is an important factor given the considerable research arguing that the use of sign language is more complex than everyday languages (Gutierrez, 2002). Effect of literacy and competency in KSL is part of the objectives of this study. Case (2003) says Language is the structured form of communication agreed upon and commonly understood by a group of people. It is the expression of human communication through which knowledge, belief, and behaviour can be experienced, explained and shared. Sign language competency (literacy) is the goal for all students so that communication is comparable with age level peers (Case, 2003).

Determinants of learners' performance have been the subject of ongoing debate among educators, academics and policy makers in Kenya (Chitiyo et al., (2015). There have been many studies that sought to examine this issue and the findings of these studies point out to hard work and discipline, previous schooling, parents' education, family income, teacher competencies and self-motivation as factors that can explain differences in learners' grades.

This study intends to determine the relationship between interpretation of Kenya sign language as a means of communication and academic performance of pupils with hearing impairment.

Sign language interpretation is an essential support service for many deaf students, but until recently, little was known about how well deaf students learned via interpreting sign language symbols (Harrington, 2000; Lang, 2002). In what appears to have been the first examination of this issue, Jacobs (1977) demonstrated that deaf college students who depended on sign language interpreting learned significantly less from classroom instruction than hearing peers. His study involved written tests, but similar findings have been obtained when learning assessments were signed (Marschark, Sapere, Convertino, Seewagen, \& Maltzan, 2004). Marschark, Sapere, et al. (2004) compared learning via (American Sign Language [ASL]) interpreting and (English) transliteration by deaf college students who varied in their ASL and Englishbased sign language skills. Regardless of how tests were administered, there were no effects of mode of interpreting and no interactions with student language skills. Similar results were obtained by Murphy and Fleischer (1977), Marschark, Sapere, Convertino, and Seewagen (2005b), and Marschark et al. (2005); Livingston, Singer \& Abramson (1994). Moreover, the studies included comparison groups have consistently replicated Jacobs' finding that deaf students learned significantly less in interpreted settings than their hearing peers did.

Findings indicating that deaf students do not comprehend as much as we (or they) think they do from interpreted lectures do not appear to be the result of any methodological or demographic confounding (Napier \& Barker, 2004). Across all the studies by Marschark and his colleagues, including a meta-analysis of those studies conducted byFabich (2005), analyses of a variety of demographic and communication variables failed to yield any consistent predictors of 
learning from signed lectures. In particular, those studies have not found differences in deaf college students' learning as a function of degree of hearing loss, parental hearing status, the age at which they learn to sign, their English-based signing or American Sign Language (ASL) skills, or several academic measures. Although the search for predictors continues, it appears that the heterogeneity of deaf students- even just those attending college, is such that we are unlikely to find any simple answers (Marschark, 1993).

Demonstrations of deaf students' limited learning in interpreted settings also cannot be explained by some inherent inferiority of learning via mediated instruction relative to direct instruction. Two findings are revealing in this regard. First, Marschark et al.(2005)showed that bilingual interpreters did not differ in their performance when they learned via direct instruction (93\%) or mediated instruction (90\%) from a hearing instructor. They used a methodology almost identical to that used in the interpreting conditions of the present experiments. Twenty interpreters saw interpreted lectures (without audio) and then received a multiple-choice assessment of learning, created in collaboration with the lecturer. Ten others took the post-test without seeing the lecture. The interpreters' near-ceiling performance after seeing the interpretation contrasted with the performance of deaf college students who scored at an average level of 53\% in an almost identical interpreted condition (but including instructor voice) involving the same lectures (Marschark et al.,2005). Interpreters who did not see the lecture scored at a level (57\%) similar to that of deaf students who did see the lecture. Although it may well be that the interpreters' receptive sign language skills were superior to many of the deaf students, such a situation does not mitigate the implications of those findings for deaf students' learning through interpreting in mainstream settings.

Marschark, Convertino, Macias, et al. (2006) used an even simpler methodology that examined deaf college students' comprehension of direct communication, as in classroom interactions. Students were paired according to their primary mode of communication to play "strong" users of ASL, "strong" users of spoken English and mixed (ASL-spoken English) pairs. Comprehension of simple, one-sentence questions, in face-to-face communication, occurred only $63 \%$ of the time between signing partners, as indicated by the ability to repeat the question immediately after it was signed. This number was significantly higher than that in the case of "oral" partners, who understood each other only $44 \%$ of the time when a question was spoken. This, in turn, did not differ from the comprehension between partners who did not share a mode of communication (46\%). Thus, deaf students may have less than full comprehension of "through the air" communication, even when it is simple and direct.

Among other things, such findings suggest that deaf students face academic challenges beyond limited English literacy skills, and communication in the classroom is in need of further investigation. Various investigators, in fact, have discussed the relatively language-impoverished environments of young deaf children, regardless of their preferred mode of communication, and there can be little doubt of consequent impact on cognitive and academic development. Marschark et al. (2005a), however, argued that the consistent findings from interpreting studies are not the product of student communication skills nor interpreting per se. Rather, they suggested that all the available evidence points to differences in the way that deaf and hearing students learn and the fact that interpreted lectures largely are structured by hearing teachers for hearing students. As a result, information presented in mainstream classrooms often may not match the knowledge and learning styles of deaf students, regardless of how it is presented.

Findings questioning the effectiveness of classroom interpreting are quite recent. Well before them, the rush to educate deaf students in integrated, general education classrooms and the shortage and expense of qualified educational interpreters led to a search for alternatives to interpreting (Ahmad, 2015; Burgstahler, 2015). Notwithstanding the welldocumented reading difficulties of deaf students (Traxler, 2000), the use of printed text, with or without the aid of technology, is rapidly becoming the support service du jour, particularly in post-secondary education.

\subsection{Purpose of the Study}

The purpose of this study is to establish the influence of the interpretation of Kenyan Sign Language (KSL) by pupils and academic performance of pupils with hearing impairment in selected primary schools in western Kenya.

\subsection{Specific Objective}

To find out the effect of learners' interpretation of KSL on academic performance of learners with hearing impairment.

\subsection{Research hypothesis}

The study will seek to test the following null research hypothesis:

- $\mathrm{Ho}_{1}$ There is no significant relationship between learners' interpretation of KSL and academic performance of learners with HI in Kenyan Primary schools.

\section{Research Design and Methodology}

\subsection{Research Design}

The researcher adopted a cross-sectional descriptive survey design to provide detailed analysis of the study population and was suitable for a study due to its ability to rapidly collect data in an extensive nature (Willis \& David, 2005). This design enable the researcher to collect data simultaneously at various levels of study in the schools. In this case, class 7 and 8 pupils, teachers attending to hearing impaired pupils and head teachers were used for study at the same time. 


\subsection{Target Population, Sampling Techniques and Sample Size}

This study targeted a total of 12 special schools namely (Mundika, Givavei, Ebukuya, Chekombero, Kakamega, Mumias, Mwikhomo, Eregi, St. Antony, Kabuchai and Kimwanga schools for the deaf),for the pupils with hearing impairment in Western Kenya, 93 sign language teachers and 108 class seven and eight pupils from public primary schools for the learners with hearing impairment in the region(Table 2).Given the small number of the teachers, pupils and head teachers, all of them were included in the study. Gay (1992) observes that the larger the sample the smaller the sampling error.

\begin{tabular}{|c|c|c|}
\hline Stratum & Target Population & Sample Size \\
\hline H/ Teachers & 12 & 12 \\
\hline Teachers & 93 & 93 \\
\hline Pupils & 108 & 108 \\
\hline Total & 213 & 213 \\
\hline
\end{tabular}

Table 2: Target population and Sample Size

\section{Results and Discussion}

\subsection{Effect of Pupils' Interpretation of KSL on Academic Performance}

The perceptions of teachers and pupils are presented in table 4.5 . The study established that $4.6 \%$ of the pupils strongly disagreed and $4.6 \%$ disagreed that pupil's ability to interpret English words in KSL affects their academic performance while $48(44.4 \%)$ agreed and $45(41.7 \%)$ strongly agreed that indeed the ability of the pupils to interpret KSL has overall effects on their academic performance while $4.6 \%$ were undecided. A cumulative $9.7 \%$ of the teachers disagreed that ability to interpret KSL by pupils affects their academic performance while $83.9 \%$ agreed that indeed pupil's ability to interpret KSL affects their academic performance. The results indicated that the importance of interpretation of sign language in teaching and learning. All the head teachers $12(100 \%)$ also emphasized the ability to interpret KSL as being key in academic performance. The studies by Nyakundi et al. 2016) and Mweri (2016) in their assessment of the KSL on performance of the learners.

\begin{tabular}{|c|c|c|c|c|}
\hline Pupils & Frequency & Percent & Valid Percent & Cumulative Percent \\
\hline \multicolumn{5}{|c|}{ Pupils } \\
\hline Strongly disagree & 5 & 4.6 & 4.6 & 4.6 \\
\hline Disagree & 5 & 4.6 & 4.6 & 9.3 \\
\hline Undecided & 5 & 4.6 & 4.6 & 13.9 \\
\hline Agree & 48 & 44.4 & 44.4 & 58.3 \\
\hline Strongly Agree & 45 & 41.7 & 41.7 & 100 \\
\hline Total & 108 & 100 & 100 & \\
\hline \multicolumn{5}{|c|}{ Teachers } \\
\hline Strongly disagree & 2 & 2.2 & 2.2 & 2.2 \\
\hline Disagree & 7 & 7.5 & 7.5 & 9.7 \\
\hline Undecided & 6 & 6.5 & 6.5 & 16.1 \\
\hline Agree & 36 & 38.7 & 38.7 & 54.8 \\
\hline Strongly agree & 42 & 45.2 & 45.2 & 100 \\
\hline Total & 93 & 100 & & \\
\hline
\end{tabular}

Table 3: Pupils Ability to Interpret English Word in KSL Affects Their Academic Performance

\subsection{Translation of KSL Signed Exact English and Academic Performance of Pupils}

The study established that $26.9 \%$ of the pupils strongly agreed that pupil's ability to translate KSL to signed exact English affects their academic performance. A significant percent at $43.5 \%$ agreed that ability of the pupil to translate KSL signed exact English affects their academic performance while 3.7\% strongly disagreed. The study further showed that 9.3\% of the pupils disagreed that their ability to translate KSL to signed exact English affects their academic performance $45.2 \%$ of the teachers strongly agreed that ability of the pupils to translate the KSL sign to exact English affects their academic performance while $38.7 \%$ of them agreed. Only $6.5 \%$ of the teachers were undecided while two (2.2\%) of them strongly disagreed. The results indicated that both teachers and pupils' value translation of sign language into understood English language. The same view was held by head teachers. In coastal region, George\& Nyakwara, (2013) found that the perception of the pupils' and teachers on KSL was that it influenced learners' performance. This was also supported by both Nyakundi et al. (2016) and Mweri (2016). 


\begin{tabular}{|c|c|c|c|c|}
\hline Perception & Frequency & Percent & Valid Percent & Cumulative Percent \\
\hline \multicolumn{5}{|c|}{ Pupils } \\
\hline Strongly disagree & 4 & 3.7 & 3.7 & 3.7 \\
\hline disagree & 10 & 9.3 & 9.3 & 13.0 \\
\hline Undecided & 18 & 16.7 & 16.7 & 29.6 \\
\hline Agree & 47 & 43.5 & 43.5 & 13.1 \\
\hline Strongly Agree & 29 & 26.9 & 26.9 & 2.0 \\
\hline Total & 108 & 100.0 & 100.0 & 9.7 \\
\hline \multicolumn{5}{|c|}{ Teachers } \\
\hline Strongly disagree & 2 & 2.2 & 2.2 & 16.1 \\
\hline Disagree & 7 & 7.5 & 7.5 & 100.0 \\
\hline Undecided & 6 & 6.5 & 6.5 & 38.7 \\
\hline Agree & 36 & 38.7 & 38.7 & 10.2 \\
\hline Strongly agree & 42 & 45.2 & 45.2 & \\
\hline Total & 93 & 100.0 & 100.0 &
\end{tabular}

Table 4: Translation of KSL Signed Exact English and Academic Performance of Pupils

\subsection{Interpretation of Finger Spelled Words and Academic Performance}

The findings of the study revealed that majority of the pupils $43.5 \%$ agreed that ability to quickly interpret the finger spelled words during instruction impacted on their academic performance while 29 (26.9\%) of them strongly agreed. The research also established that $16.7 \%$ of the pupils were undecided while another $10(9.3 \%)$ disagreed with the statement. The other 4 (3.7\%) of them $2.2 \%$ strongly disagreed. It was further noted that $48.4 \%$ of the teachers strongly agreed that ability of the pupils to quickly interpret the finger spelled words during instruction affects academic performance of the pupils while $9.7 \%$ disagreed while another $6.5 \%$ of them were undecided and $6.5 \%$ strongly disagreed. Results showed that majority of learners, teachers and head teachers as interviewed agreed that quick interpretation of finger spelled words affects performance. Hill-Miller, P. (2011). Established that pupils would be influenced by the speed to interpret the finger spelled words and thus influenced their academic performance.

\begin{tabular}{|c|c|c|c|c|}
\hline \multicolumn{5}{|c|}{ Pupils } \\
\hline & Frequency & Percent & Valid Percent & Cumulative Percent \\
\hline Strongly disagree & 4 & 3.7 & 3.7 & 3.7 \\
\hline Disagree & 10 & 9.3 & 9.3 & 13.0 \\
\hline Undecided & 18 & 16.7 & 16.7 & 29.6 \\
\hline Agree & 47 & 43.5 & 43.5 & 73.1 \\
\hline Strongly Agree & 29 & 26.9 & 26.9 & 100.0 \\
\hline Total & 108 & 100.0 & 100.0 & \\
\hline \multicolumn{5}{|c|}{ Teachers } \\
\hline Strongly disagree & 6 & 6.5 & 6.5 & 6.5 \\
\hline Disagree & 9 & 9.7 & 9.7 & 16.1 \\
\hline Undecided & 6 & 6.5 & 6.5 & 22.6 \\
\hline Agree & 27 & 29.0 & 29.0 & 51.6 \\
\hline Strongly agree & 45 & 48.4 & 48.4 & 100.0 \\
\hline Total & 93 & 100.0 & 100.0 & \\
\hline
\end{tabular}

Table 5: Effect of Pupils Ability to Interpret Finger Spelled Words on Performance

\subsection{Pupils' Ability to Differentiate Signed Word from Signer Spelled Words Language}

The study noted that $30(27.8 \%)$ of the pupils strongly agreed that their ability to differentiate signed word from finger spelled word in sentence construction affects their performance while $49(45.4 \%)$ simply agreed that it affected their academic performance while 10 (9.3\%) of them were found to be undecided (table 6). 


\begin{tabular}{|c|c|c|c|c|}
\hline \multicolumn{5}{|c|}{ Pupils } \\
\hline & Frequency & Percent & Valid Percent & Cumulative Percent \\
\hline Strongly disagree & 13 & 12.0 & 12.1 & 12.1 \\
\hline Disagree & 5 & 4.6 & 4.7 & 16.8 \\
\hline Undecided & 10 & 9.3 & 9.3 & 26.2 \\
\hline Agree & 49 & 45.4 & 45.8 & 72.0 \\
\hline Strongly Agree & 30 & 27.8 & 28.0 & 100.0 \\
\hline Total & 107 & 99.1 & 100.0 & \\
\hline Total & 108 & 100.0 & \multicolumn{1}{l|}{} \\
\hline \multicolumn{5}{|c|}{ Teachers } \\
\hline Strongly disagree & 9 & 9.7 & 9.7 & 22.6 \\
\hline Disagree & 12 & 12.9 & 12.9 & 37.6 \\
\hline Undecided & 14 & 15.1 & 15.1 & 100.9 \\
\hline Agree & 30 & 32.3 & 32.3 & \\
\hline Strongly agree & 28 & 30.1 & 30.1 & 100.0 \\
\hline Total & 93 & 100.0 & 10.0 &
\end{tabular}

Table 6: Pupils Ability to Differentiate Signed Word from Signer Spelled Words Language

The research established that $4.6 \%$ of the pupils disagreed that their ability to differentiate word from finger spelled words in sentence affects their academic performance. The other 13 (4.6\%) strongly disagreed. Only 28 (30.1\%) of the teachers also strongly agreed that ability of pupils to differentiate signed word from finger spelled word in sentence construction affected their performance, 30 (32.3\%) agreed while 14 (15.1\%) of them were undecided. The findings also showed that12 (12.9\%) of the teachers disagreed with the statement while $9(9.7 \%)$ of them strongly disagreed. Majority learners and teachers viewed differentiating signed word from word finger spelled do affect performance (table 4.8). Interviewed head teachers have a similar stand.

\subsection{Testing of the Null Hypothesis}

In order to determine the relationship between the independent variable (Mastery of KSL) and the dependent variable (teaching and learning expressed in terms of KCPE mean scores) Chi-square was used at the significance level of $\mathrm{p}<0.05$.

\subsection{The Chi-Square Results for How Mastery of KSL Influences Teaching and Learning}

The study sought to determine how mastery of LSL influenced teaching and learning in public primary schools in western region. To accomplish this, Chi-square was used to test the effects of interpretation of KSL, teaching learning as expressed in terms of KCPE performance. The results of the analysis are summarized in table 7 and 8 for the teachers and Pupils respectively.

\subsubsection{Hypothesis $\mathrm{H}_{0} 1$}

There is no significant relationship between mastery of KSL and academic performance. The results of the analysis summarized in table 7 and 8 shows that there was significant relationship between interpretation of Kenyan sign language and teaching and learning at $p=0.003$ and $p=0.001(p<0.05)$. The study therefore rejected the null hypothesis and concluded that interpretation of KSL has significant effect on the teaching and learning.

\begin{tabular}{|c|c|c|}
\hline Mean Score-2013-2017 & $\begin{array}{c}\text { KSL } \\
\text { Interpretation }\end{array}$ & $\begin{array}{c}\text { Mean score } \\
\mathbf{2 0 1 4 - 1 8}\end{array}$ \\
\hline Chi-Square & $176.528^{\mathrm{a}}$ & \\
\hline Df & 43 & \\
\hline Asymp. Sig. & .003 & \\
\hline
\end{tabular}

Table 7: Chi-Square for the Teachers' Responses

\begin{tabular}{|l|l|l|}
\hline & \multicolumn{1}{|c|}{ KSL interpretation } & \multicolumn{1}{c|}{$\begin{array}{c}\text { Mean score } \\
\mathbf{2 0 1 4 - 1 8}\end{array}$} \\
\hline Chi-Square & $162.583^{\mathrm{a}}$ & \\
\hline Df & 13 & \\
\hline Asymp. Sig. & 0.001 & \\
\hline
\end{tabular}

Table 8: Chi-Square of the Curriculum

Practices for the Class Prefects' Responses 


\section{Conclusions and Recommendations}

\subsection{Conclusion}

Master of KSL by teachers has significant influence on academic performance of learners with hearing impairment. The teachers understanding of KSL determines the extent to which they are able to give instruction to the pupils in similar language being the language of instruction. This in turn affects the academic performance of learners in English, Mathematics and Science since the mastery of KSL by teachers influences the understanding of pupils in the subjects. Learners with hearing impairment faces various difficulties in using such as ignorance among parents and other stakeholders, unavailability of resources and inadequate knowledge of teachers in KSL affects their learning process. These difficulties affect the learners with hearing impairment in using KSL both inside and outside classroom.

Master of Kenya Sign Language by teacher and pupils ensures wide covered of the curriculum content within a short time. When both pupils and teachers have good understanding of the KSL, the pupils are able to grasp the curriculum content much faster and therefore they teachers take lesser time to cover all the content and with sea. On the other hand when both teachers and pupils have little understanding of the KSL, then the curriculum content might not be adequately covered by the teachers because both teachers and pupils will be struggling to understand the contents. These descriptive research results were supported by the chi- square results where mastery of KSL has significant effect on academic performance at $\mathrm{p}<0.05$.

\subsection{Recommendation}

The study recommends that there is for programs to enlighten and adequate community and other stakeholders on the importance of supporting pupils with hearing impairment to learn and understand Kenya Sign Language. Such programs should be geared towards having the community including parents to support the government efforts to provide KSL among learners with hearing impairment at an early age. The government should also train and deploy more teachers to schools with learners with hearing impairment as one of the challenges facing the learners with hearing impairment was inadequate rained and skilled teachers. This move should be geared towards reducing the number of Teacher to pupils ration and enable the teachers to give personal attention to learners.

Since mastery of KSL among teachers have a direct influence on academic performance of learners with hearing impairment, the study recommends that the government should consider supporting teachers to enable them advance their education and acquire additional skills on KSL as a long term strategy or increased performance among learners with hearing impairment.

\section{References}

i. Abang, T. (1995). Handbook of special education for educators in developing countries.Jos: Fab Educational Books.

ii. Abiodun, K. (2006). Speech and language disorders. In J.N. Onwuchekwa (Ed). A comprehensive textbook of special education. Ibadan: Agbo Areo.

iii. Abiodun, K. (2006). Speech and language disorders. In J.N. Onwuchekwa (Ed). A comprehensive textbook of special education. Ibadan: Agbo Areo.

iv. Abriza, A., \& Ahmad, R. (2017). Systemic barriers: the challenges in the provision of inclusive school libraries in Malaysia. Malaysian Journal of Library \& Information Science, 15(2), 19-40.

v. Ademokoya, J.A. (1995). Effects of direct and indirect strategies on reasoning skills in some secondary school of hearing-impaired students. An unpublished Ph.D Thesis Department of Special Education, University of Ibadan.

vi. Ademokoya, J.A. (1995). Effects of direct and indirect strategies on reasoning skills in some secondary school of hearing-impaired students. An unpublished Ph.D Thesis Department of Special Education, University of Ibadan.

vii. Ademokoya, J.A. (2006). Audiology: Hearing loss, communication disorders and Adolescence. 20, 863-875.

viii. Adoyo, P. O. (2002). Emergent approaches towards sign bilingualism in deaf education in Kenya. Vienna Journal of African Studies, 3, 83-96. Retrieved from http:/ / www.univie.ac.at/ ecco/ stichproben/ Nr3 OrachaAdoyo.pdf

ix. Adoyo, P. O. (2004). Kenyan Sign Language and Simultaneous Communication: Differentiated effects on memory and comprehension in deaf children in Kenya. Kisumu: Lake Publishers \& Enterprise Ltd.

x. Ahmad, F. K. (2015). Exploring the invisible: Issues in identification and assessment of students with learning disabilities in India. Transcience: A Journal of Global Studies, 6(1), 91-107.

xi. Alade, E.B. (1992). Evaluation of the hearing-impaired. Ibadan: Centre for External education. Boston: Allynand Bacon.

xii. Alikali, H.S. (1991). Education of the hard-of-hearing: A forgotten alternative in Nigeria. audiological interventions. In J.N. Onwuchekwa (Ed.) A comprehensive textbook of special education. (2ndedition). Ibadan: Agbo Areo. pp. 19-28.

xiii. Aura, L. J., Venville, G., \& Marais, I. (2016). The relationship between Kenyan sign language and English literacy. Issues in Educational Research, 26(2), 165-181.

xiv. Awori, B. B. (2010). The Relationship Between Self-Esteem and Academic Achievement of Girls with Hearing Impairments in Secondary Schools for the Deaf in Kenya. JAASEP, 2010(Spring/ Summer), 38-51.

xv. Ayiela, O.J. (2012). Factors affecting KCPE performance of learners with hearing impairments in special schools in selected counties, Kenya. Unpublished thesis, Kenyatta University.

xvi. Bakare, C.A. (1988). Audiological assessment of the Nigerian child. In O.C. Abosi, (Ed.) Development of special education in Nigeria. Ibadan: Fountains Books. 
xvii. Barron, S. (2016). 'Thinking it Savors of the Miraculous': The Manitoba Institute for the Deaf and Dumb and the Growth of Deaf Public Life in Manitoba, 1884-1909 (Doctoral dissertation, University of Calgary).

xviii. Best, J. W. \& Kahn, J. R. (2006). Research in Education. (10thed.). New Delhi: Prentice Hall.

xix. Biehler, R.F. (1981). Child development: An introduction. Boston: Houghton Mifflin Company.

xx. Burgstahler, S. (2015). Opening doors or slamming them shut? online learning practices and students with disabilities. Social Inclusion, 3(6), 69-79.

xxi. Chesire, D. K. (2018). Selected institutional teacher motivation practices and their influence on Kiswahili instruction in Baringo County: a study of public primary schools (Doctoral dissertation, Moi University).

xxii. Chitiyo, M., Odongo, G., Itimu-Phiri, A., Muwana, F., \& Lipemba, M. (2015). Special education teacher preparation in Kenya, Malawi, Zambia, and Zimbabwe. Journal of International Special Needs Education, 18(2), 51-59.

xxiii. Choi, S. M. R., Kei, J., \& Wilson, W. J. (2019). Hearing and Auditory Processing Abilities in Primary School Children with Learning Difficulties. Ear and hearing, 40(3), 700-709.

xxiv. Clark, M. D., Hauser, P. C., Miller, P., Kargin, T., Rathmann, C., Guldenoglu, B., ... \& Israel, E. (2016). The importance of early sign language acquisition for deaf readers. Reading \& Writing Quarterly, 32(2), 127-151.

xxv. Daub, O., Bagatto, M. P., Johnson, A. M., \& Cardy, J. O. (2017). Language outcomes in children who are deaf and hard of hearing: The role of language ability before hearing aid intervention. Journal of Speech, Language, and Hearing Research, 60(11), 3310-3320.

xxvi. Easterbrooks, S. R., \& Stephenson, B. M. (2006). Master teachers' responses to twenty literacy and science/ mathematics practices in deaf education. American Annals of the Deaf, 151(4), 398-409.

xxvii. Enns, C., Hall, R., Isaac, B., \& MacDonald, P. (2007). Process and Product: Creating Stories with Deaf Students. TESL Canada Journal, 25(1), 1-22.

xxviii. Fabich, M. (2005). A meta-analysis of demographic characteristics and learning by deaf students. Rochester Institute of Technology; Rochester, NY. Unpublished master's thesis.

xxix. Friend, M. (2007). Special Education: Contemporary Perspectives for school professionals (2nd ed.). Boston: Pearson/ Allyn and Bacon.

xxx. Garrote, A., Dessemontet, R. S., \& Opitz, E. M. (2017). Facilitating the social participation of pupils with special educational needs in mainstream schools: A review of school-based interventions. Educational Research Review, $20,12-23$.

xxxi. George, G. E., \& Nyakwara, W. J. M. S. (2013). Quality assurance standards in the management of school curriculum: Case of schools for the deaf in coast counties, Kenya. Quality Assurance, 3(3).

xxxii. Gesel, A. (1954). Ontogenesis of infant behaviour. In L. Carmichael (Ed). Manual of the child psychology. New York: Willey.

xxxiii. Gibson, F., Fern, L., Oulton, K., Stegenga, K., \& Aldiss, S. (2018). Being Participatory Through Interviews. In Being Participatory: Researching with Children and Young People (pp. 103-126). Springer, Cham.

xxxiv. Hallahan, D. P. \& Kauffman, J.M. (1994). Exceptional children: Introduction to special education. Jos: National Council for Exceptional Children.

xxxv. Harrington F. (2000). Sign language interpreters and access for deaf students to university curricula: The ideal and the reality. In: Roberts RP, Carr SE, Abraham D, Dufour A, editors. The critical link 2: Interpreters in the community. John Benjamins; Amsterdam, The Netherlands: 2000. pp. 219-273.

xxxvi. Heslinga, V. (2012). Sign language and ELLs in the heterogeneous classroom. Paxton.

xxxvii. Heward, W. L. (2000). Exceptional children: An introduction to special education. New Jersey: Prentice.

xxxviii. Hill-Miller, P. (2011). Different approach, different results: A study of mastery learning instruction in a developmental reading class at an urban community college. Unpublished PhD Dissertation). University of North Carolina at Charlotte, North Carolina, USA.

xxxix. Idris, R. G., \& Badzis, M. (2017). Interpersonal behavioural problems in children with Hearing impairment: the parental experiences and coping Strategies. International Journal of Education and Research, 5(10), 223-236.

xl. Imbiti, B., Awori, B., \& Kwena, J. (2014). Strategies facilitation Kenyan Sign Language Process in Primary Schools for Learners with Hearing Impairments, in Western Province, Kenya. International Journal of Education and Research, 2(1), 1-14.

xli. Jacobs, L. R. 1977). The efficiency of interpreting input for processing lecture information by deaf college students. Journal of Rehabilitation of the Deaf 11:10-14.

xlii. Johnson, C.D. (1987). Educational management of the hearing-impaired child. In J.G. Alpiner, and P.A. McCarthy, (Eds.) Rehabilitative audiology: Children and adults. Baltimore Williams and Wilkins. pp. 89-107.

xliii. Katitia, D. M. O. (2015). Teacher Education Preparation Program for the 21st Century. Which Way Forward for Kenya?Journal of Education and Practice, 6(24), 57-63.

xliv. KILANYA, A. (2016). EFFECTS OF KENYAN SIGN LANGUAGE ON ACQUISITION OF ENGLISH LANGUAGE: A STUDY OF ESAGERI SCHOOL FOR THE DEAF, MOGOTIO, BARINGO COUNTY, KENYA (Doctoral dissertation, KENYATTA UNIVERSITY).

xlv. Kimani, C. W. (2012). Teaching deaf learners in Kenyan classrooms. Diss. University of Sussex.

xlvi. Kirk, S.A. \& Gallagher, J.J. (1989). Educating exceptional children. New Jersey: Hiughton Mifflin Company.

xlvii. Kluwin, T. N., \& Stewart, D. A. (2001). Teaching deaf and hard of hearing students: Context, Strategies and Curriculum. Boston: Allyn \& Bacon.

xlviii. Kluwin, T.N. (1985). Profiling the deaf student who is a problem in the classroom Studies, University of Ibadan. 
xlix. Knapp, M., Cambridge, P., Thomason, C., Beecham, J., Allen, C., \& Darton, R. (2018). Care in the community: Challenge and demonstration. Routledge.

l. Kothari, C. R. (2004). Research Methodology: Methods and Techniques. New Delhi: New Age International Publishers.

li. Kumar, D. N., Kumar, P., \& Rawat, J. S. (2017). Education of persons with visual disabilities in India. International Journal of Development Research, 7(08), 14757-14761.

lii. Lang, H. G. (2002). Higher education for deaf students: Research priorities in the new millennium. Journal of Deaf Studies and Deaf Education 7:267-280.

liii. Lang, H. G., \& Albertini, J. A. (2001). Construction of Meaning in the Authentic Science Writing of Deaf Students. Journal of Deaf Studies and Deaf Education, 6(4), 258-284. https:/ / doi.org/ 10.1093/ deafed/ 6.4.258

liv. Lang, H. G., Hupper, M. L. P., Monte, D. A., Brown, S. W., Babb, I., \& Scheifele, P. M. (2006). A study of technical signs in science: Implications for lexical database development. Journal of Deaf Studies and Deaf Education, 12(1), 6579. https:/ / doi.org/ 10.1093/ deafed/ enl018

lv. Marschark, M. (1993). Psychological development of deaf children. Oxford University Press; New York.

lvi. Marschark, M., \& Spencer, P. E. (2006). Spoken language development of deaf and hard-of-hearing children: Historical and theoretical perspectives. Advances in the spoken language development of deaf and hard-ofhearing children, 3-21.

lvii. Marschark, M., Convertino, C., Macias, G., Monikowski, C. M., Sapere, P., \& Seewagen, R. (2006). Understanding communication among deaf students who sign and speak: A trivial pursuit?

lviii. Marschark, M., Sapere, P., Convertino, C., Seewagen, R., \& Maltzan, H. (2000) Comprehension of sign language interpreting: Deciphering a complex task situation. Sign Language Studies 4:345-368.

lix. Marschark, M., Walton, D., Crowe, K., Borgna, G., \& Kronenberger, W. G. (2018). Relations of social maturity, executive function, and self-efficacy among deaf university students. Deafness \& Education International, 20(2), 100-120.

lx. Marschark. M., Sapere, P., Convertino, C., \& Seewagen, R. (2005b). Access to postsecondary education through sign language interpreting. Journal of Deaf Studies and Deaf Education 10:38-50.

lxi. Mba, P.O. (1981). Language and the deaf child. Journal of Special Education.1 (2); 20-23.

lxii. Mba, P.O. (1995). Fundamentals of special education and vocational rehabilitation. Ibadan: Codat.

lxiii. Ministry of Education. (2004). Primary Education syllabus for learners with hearing impairments: Kenyan Sign Language. Nairobi: Ministry of Education.

lxiv. Ministry of Education. (2009). The National Special Needs Education Policy Framework. Nairobi: Ministry of Education.

lxv. Miyamoto, R., \& Mori, S. (2015). Is Kenyan Sign Language a sister language of ASL?Japanese Journal of Sign Language Studies, 24, 17-30.

lxvi. Mogen, K. S. (2013). Mastery learning instruction versus traditional instructional methods in eighth grade language arts (Doctoral dissertation, North Dakota State University).

lxvii. Mugenda, O. M. \& Mugenda, A. G. (1999). Research Methods. Nairobi: Acts Press.

lxviii. Mugenda, O. M. \& Mugenda, A. G. (2003). Research Methods. Nairobi: Acts Press.

lxix. Mweri, G. J. (2016). The acquisition of Kenyan Sign Language (KSL) and its significance as a mother tongue and medium of instruction in schools for the deaf in Kenya. University of Nairobi Journal of Language and Linguistics, 5, 85-100.

lxx. Napier, J., \& Barker, R. (2004). Access to university interpreting: Expectations and preferences of deaf students. Journal of Deaf Studies and Deaf Education 9:228-238.

lxxi. Napier, J., \& Leeson, L. (2016). Sign language in action. In Sign Language in Action (pp. 50-84). Palgrave Macmillan, London.

lxxii. Nasibi, W. M. W. (2003). Instructional methods -Teaching Across curriculum. Nairobi: Strongwall Africa.

lxxiii. Ndurumo, M. M. (1993). Exceptional children: Developmental consequence and interventions. Nairobi: Longman.

lxxiv. Nyakundi, H. K., Awori, B. B., \& Chege, P. M. (2016). Effectiveness of Placement Options for Learners with Hearing Impairment in Kajiado North Sub-County, Kajiado County, Kenya. International Journal of Arts and Commerce, 5(7), 61-76.

lxxv. Ogada, R. (2014). Languages used in Teaching and Learning English Composition writing among learners with hearing impairments in Nyanza Province, Kenya. International Journal of Social Sciences and Entrepreneurship, $1(12), 1-11$.

lxxvi. Ogada, R., Oracha, P., Kochung, E. J., \& Matu, P. M. (2012). Strategies used in teaching English composition to learners with hearing impairment in Nyanza. Journal of Emerging Trends in Educational Research and Policy Studies, 3(5), 638-645.

lxxvii. Sambu, M. C., Otube, N., \& Bunyasi, B. A. (2018). ASSESSMENT OF ACADEMCPERFORMANCE OF LEARNERSWITH HEARING IMPAIRMENT IN SELECTED SPECIAL PRIMARY SCHOOLS IN KENYA. Retrieved from https:/ / www.ijern.com/ journal/ 2018/ February-2018/ 04.pdf

lxxviii. Sandler, W., \& Lillo-Martin, D. (2009). Sign Language and Linguistic Universals. New York: Cambridge University Press.

lxxix. Santau, A. O., Secada, W., Maerten-Rivera, J., Cone, N., \& Lee, O. (2010). US urban elementary teachers' knowledge and practices in teaching science to english language learners: Results from the first year of a professional 
development intervention. International Journal of Science Education, 32(15), 2007-2032. https:/ / doi.org/ 10.1080/ 09500690903280588

lxxx. Schwab, S., Gebhardt, M., Hessels, M. G., \& Nusser, L. (2016). Predicting a high rate of self-assessed and parentassessed peer problems-Is it typical for students with disabilities? Research in developmental disabilities, 49, 196-204.

lxxxi. Schwab, S., Wimberger, T., \& Mamas, C. (2019). Fostering Social Participation in Inclusive Classrooms of Students who are Deaf. International Journal of Disability, Development and Education, 1-18.

lxxxii. Silverman, D. (2001). Interpreting qualitative data: methods for analyzing talk, text and interaction. (2nd ed.). London: Sage.

lxxxiii. Silverman, D. (2001). Interpreting qualitative data: methods for analyzing talk, text and interaction. (2nd ed.). London: Sage.

lxxxiv. Traxler, C. B. (2000). Measuring up to performance standards in reading and mathematics: Achievement of selected deaf and hard-of-hearing students in the national norming of the 9th Edition Stanford Achievement Test. Journal of Deaf Studies and Deaf Education, 5:337-348.

lxxxv. UNESCO, (2010a) Reaching the Marginalized, Education for All: Global Monitoring Report (Oxford/ Paris, Oxford University Press/ UNESCO)

lxxxvi. UNESCO, (2010b), UNESCO National Education Support Strategy (UNESS) for the Republic of Kenya 2010-2011, (Nairobi UNON).

lxxxvii. Willis, R and Davis, G. (1998). An introduction to sociolinguistics. Massachusetts: Blackwell Publishers Ltd. $3^{\text {rd }}$ Edition.

lxxxviii. Wu, J., Tian, Z., Sun, L., Estevez, L., \& Jafari, R. (2015, June). Real-time American sign language recognition using wrist-worn motion and surface EMG sensors. In 2015 IEEE 12th International Conference on Wearable and Implantable Body Sensor Networks (BSN) (pp. 1-6). IEEE.

lxxxix. Zarchy, R. (2008). Deaf Language Acquisition and Transfer to Literacy. Retrieved December from http:/ / razisignlanguage.blogspot.co.za/ 